\title{
PENGARUH GOOD CORPORATE GOVERNANCE DAN LEVERAGE TERHADAP KINERJA KEUANGAN PERBANKAN YANG TERDAFTAR DI BURSA EFEK INDONESIA
}

\author{
Capry Dudellah Rode, Aminar Sutra Dewi \\ Sekolah Tinggi Ilmu Ekonomi KBP \\ cdudellahrode@gmail.com
}

\begin{abstract}
The performance of several issuers in the first quarter of 2017 was better. In fact, some banks reported an increase in net income over the same period the previous year. The role of the organization in the company will affect the company performance. This study aims to determine the effect of Managerial Ownership, Board of Directors, and the influence of Corporate Financial Performance. The sample used is the financial sector companies in 2012-2016 amounted to 40 samples. The type of data used is secondary data. The hypothesis in this study was tested by using panel data regression. The result of hypothesis testing shows that Managerial Ownership has positive and insignificant effect on Financial Performance (ROA), Board of Directors has positive and significant influence to Company's Financial Performance (ROA) and Leverage have positive and insignificant influence to ROA's Financial Performance.
\end{abstract}

Keywords: Managerial Ownership, Board of Directors, Leverage, and ROA

\section{PENDAHULUAN}

Kinerja beberapa emiten perbankan pada triwulan- I 2017 tercatat membaik. Bahkan, beberapa bank melaporkan meraih peningkatan laba bersih dibandingkan periode sama tahun sebelumnya. PT Bank Mandiri Tbk, PT Bank Danamon Indonesia Tbk, dan PT Bank Tabungan Pensiunan Nasional Tbk (BTPN). Dengan meningkatnya laba bank menandakan kinerja keuangan bank tersebut membaik. Dan dapat memberikan dampak positif terhadap bank itu sendiri.

Beberapa bank tersebut mengalami peningkatan terhadap laba. Salah satu contohnya yaitu pada PT Bank Mandiri Tbk. Salah satu faktor yang mendorong laba yaitu karena meningkatnya pembiayaan, itu terlihat dari pertumbuhan kredit secara tahunan pada triwulan pertama 2017. Peningkatan laba ini berdampak baik terhadap perusahaan, dimana para investor akan tertarik untuk menanamkan modalnya pada perusahaan tersebut. Dengan hal ini tujuan utama dari perbankan yaitu menyalurkan kredit akan meningkat dengan adanya peningkatan pembiayaan. Selain itu kinerja perusahaan untuk memperoleh laba juga ditopang oleh kredit perseroan yang meningkat. Sehingga akan berdampak pada kualitas aset yang membaik yang disebabkan oleh pertumbuhan pembiayaan dan juga peningkatan pada penyaluran kredit.

Terdapat satu hal yang tidak dapat dipisahkan dalam menghubungkan struktur kepemilikan dengan kinerja pada bank. Yaitu kepengurusan dalam manajemen bank itu sendiri. Oleh sebab itu hubungan antara manajemen suatu 
bank dengan pemilik bank akan dibentuk dalam suatu kontrak (performance contract).yaitu kesepakatan antara pemilik saham serta dengan manajemen perusahaan tersebut akan sejalan dengan Agency Theory (Jensen dan Meckling, 1976).

Kinerja keuangan juga di pengaruhi oleh Good Corporate Governance. Good Corporate Governance merupakan syistem yang mampu memberikan perlindungan dan jaminan hak kepada stake holders, termasuk didalamnya adalah shareholders, lenders, employees, government, executives costumer dan stakeholders yang lain. Salah satu variabel dalam good corporate governance yaitu kepemilikan manajerial. Struktur kepemilikan berkemampuan untuk memberi pengaruh terhadap kinerja perusahaan dengan mempengaruhi jalan perusahaan. Kepemilikan manajerial dapat di ukur dengan melihat persentase kepemilikan pihak manajemen.

Kepentingan manajer dan pemegang saham disejajarkan oleh kepemilikan saham oleh manajer karena manfaat akan dirasakan langsung oleh manajer dari setiap keputusan yang diambil, begitu juga sebaliknya Jensen dan Meckling (1976). Kepemilikan manajerial dapat di ukur dengan melihat persentase kepemilikan pihak manajemen (Sabrina, 2010). Berdasarkan hasil penelitian yang dilakukan oleh (Ardianingsih \& Ardiyani, n.d.) mengatakan bahwa struktur kepemilikan manajerial dan variabel Return on asset (ROA) yang berpengaruh signifikan terhadap kinerja perusahaan. Sehingga dapat ditarik Hipotesis pertama bahwa diduga Kepemilikan Manajerial berperngaruh Positif dan Signifikan terhadap Kinerja Keuangan.

Kebijakan jangka pendek maupun jangka panjang akan diambil ditentukan oleh Dewan Direksi (Bodroastuti, 2009). Dewan direksi dalam penelitian ini diukur dengan menggunakan jumlah dewan direksi. Jumlah dewan direksi yang lebih sedikit akan menciptakan komunikasi yang lebih baik di antara para direktur, koordinasi yang lebih efektif, dan tindakan yang lebih cepat dalam mengatasi masalah. Berdasarkan hasil penelitian yang dilakukan oleh (Widyati, 2013) mengatakan bahwa dewan direksi yang di ukur dengan jumlah dewan direksi tidak berpengaruh signifikan terhadap kinerja keuangan perusahaan. Dari hasil peneltian tersebut ditarik Hipotesis kedua bahwa diduga jumlah Dewan Direksi tidak berpengaruh positif dan Signifikan terhadap Kinerja Keuangan.

Leverage menunjukkan kemampuan suatu perusahaan dalam membayarkan hutangnya equity yang milikinya. Apabila leverage tinggi, maka risiko suatu perusahaan tinggi pula. Pertimbangan dalam mengambil keputusan untuk keputusan investasi para investor menghindari nilai saham yang tinggi yang dapat menyebabkan penilain harga saham perdana terlalu tinggi sehingga menyebabkan terjanya underpricing. Penelitian yang dilakukan oleh (Yulianawati, 2014) mengatakan bahwa leverage berpengaruh negatif terhadap kinerja keuangan karna ditemukan pada tingkat signifikan 5\%. Sehingga Hipotesis ketiga dapat ditarik bahwa diduga Leverage berpengaruh Negatif dan Signifikan terhadap Kinerja Keuangan Perusahaan.

\section{METODE PENELITIAN}

Penelitian ini termasuk pada penelitian kuantitatif yang mana ada angkaangka yang terdapat pada penelitian ini. penelitian kuantitatif menggunakan skala numeric, berbasis pola alur deduktif, dimana untuk menjawab rumusan masalah 
digunakan teori atau konsep untuk dapat merumuskan hipotesis.Populasi merupakan suatu wilayah generalisasi yang terdiri dari objek yang mempunyai kuantitas dan karakteristik tertentu yang ditetapkan oleh peneliti untuk di pelajari dan kemudian ditarik kesimpulannya.Oleh karena itu dapat disimpulkan bahwa populasi dapat berupa subyek (orang) ataupun objek (tempat) yang karakteristik berbeda dan bisa diteliti. Dalam penelitian ini peneliti mengambil populasi pada 43 perusahaan yang terdaftar di Bursa Efek Indonesia. , populasi yang ada akan diambil sejumlah tertentu sebagai sampel. Pengambilan sampel penelitian dilakukan dengan metode purposive sampling. sedangkan untuk teknik pengumpulan data didapat melalui Dokumentasi yang mana data bisa di dapat pada situs resmi Bursa Efek Indonesia yang telah memplubikasikan ringkasan kinerja keuangan berdasarkan objek yang dibutuhkan.

\begin{tabular}{|c|c|c|c|}
\hline VARIABEL & PENGERTIAN & INDIKATOR & SUMBER \\
\hline $\begin{array}{l}\text { Kinerja } \\
\text { Keuangan }\end{array}$ & $\begin{array}{l}\text { Kinerja Keuangan } \\
\text { Adalah pencapaian } \\
\text { prestasi perusahaan } \\
\text { pada suatu periode } \\
\text { yang menggambarkan } \\
\text { kondisi kesehatan } \\
\text { keuangan perusahaan. }\end{array}$ & CFROA $=\frac{\text { Keuntungan Bersih }}{\text { Jumlah asset }}$ & $\begin{array}{l}\text { (Widyati, } \\
\text { 2013) }\end{array}$ \\
\hline $\begin{array}{l}\text { Kepemilikan } \\
\text { Manajerial }\end{array}$ & $\begin{array}{l}\text { kepemilikan } \\
\text { manajerial merupakan } \\
\text { alat pengawasan } \\
\text { terhadap kinerja } \\
\text { manajer yang bersifat } \\
\text { internal }\end{array}$ & $\begin{array}{l}\text { Persentase kepemilikan } \\
\text { manajerial }\end{array}$ & $\begin{array}{l}\text { Melinda, } \\
\text { F.I, dan } \\
\text { Bertha S. } \\
\text { Sutejo. } \\
\text { (2008). }\end{array}$ \\
\hline Dewan Direksi & $\begin{array}{l}\text { Dewan direksi adalah } \\
\text { anggota dewan yang } \\
\text { bertanggung jawab } \\
\text { terhadap kinerja dan } \\
\text { manajemen } \\
\text { perusahaan }\end{array}$ & $\begin{array}{l}\text { Jumlah seluruh anggota } \\
\text { dewan direksi dalam } \\
\text { perusahaan }\end{array}$ & $\begin{array}{l}\text { (Noviawa } \\
\mathrm{n}, 2013)\end{array}$ \\
\hline Leverage & $\begin{array}{l}\text { adalah suatu } \\
\text { kebijakan yang } \\
\text { dilakukan oleh suatu } \\
\text { perusahaan dalam hal } \\
\text { menginvetasikan dana } \\
\text { atau memperoleh } \\
\text { sumber dana yang } \\
\text { disertai dengan } \\
\text { adanya beban/biaya } \\
\text { tetap yang harus } \\
\text { ditanggung } \\
\text { perusahaan. Leverage } \\
\text { diukur dengan tingkat } \\
\text { hutang perusahaan. }\end{array}$ & $D E R=\frac{\text { Total Hutang }}{\text { Total Modal }}$ & $\begin{array}{l}\text { (Yulianaw } \\
\text { ati, 2014) }\end{array}$ \\
\hline
\end{tabular}




\section{Teknik Analisis Data}

Teknik analisis data yang digunakan dalam penelitian ini adalah metode analisis statistik. Analisis data menggunakan EVIEWS 8, yang dimana teknik analisis data yang digunakan oleh peneliti adalah:

1. Statistik Deskriptif Analisis

Statistik deskriptif adalah penyajian data secara numerik. Statistik deskriptif menyajikan ukuran-ukuran numerik yang sangat penting bagi data sampel. Statistik deskriptif juga digunakan untuk mengetahui nilai rata-rata, minimal, maksimal dan standar deviasi dari variabel-variabel yang diteliti.

\section{Uji Asumsi Klasik}

Uji asumsi klasik digunakan untuk menguji apakah model regresi benar-benar menunjukkan hubungan yang signifikan dan representatif. Ada tiga pengujian dalam uji asumsi klasik, yaitu:

1. Uji normalitas data

Uji normalitas menggambarkan apakah dalam model regresi, variabel penganggu atau residual terdistribusi normal. Namun Pada penelitian ini menggunakan uji statistik Jarque-Bera untuk mengetahui apakah data berdistribusi normal. Data dikatakan normal apabila Jarque-Bera lebih kecil dari 2 (tidak signifikan) atau profitabilitas lebih besar dari $\alpha 5 \%(0,05)$ maka data terdistribusi normal.

2. Uji multikolinearitas

Uji multikolinieritas diguna untuk mengetahui adakah indikasi asumsi klasik tersebut. Dapat dilihat apakah model regresi tersebut terdapat korelasi antara variabel bebas atau variabel terikat. Apabila memiliki independen lebih dari satu. Syarat tidak terjadi Multikolinieritas adalah jika nilai korelasi antar variabel independen $<0,8$. Jika nilai korelasi $>0,8$ maka terjadi multikolinieritas.

3. Uji heteroskedastisitas

Uji heteroskedastisitas adalah uji yang bergunakan untuk mengetahui didalam model regresi apakah ditemukan ketidaksamaan antara variasi dari residual antara objek satu dengan objek lainnya. Terjadinya kondisi heteroskedastisitas akan berakibat tidak mutlaknya penaksiran koefisien seperti berkurang atau berlebih dari yang semestinya.uji Rank Sparman digunakan Untuk menguji ada tidaknya heteroskedastisitas, melihat gejala heteroskedastisitas dalam data.dengan cara mengkorelasikan masing-masing nilai absolut yang residual terhadap variabel independent. Gajala ini dapat dilihat dari nilai residual yang signifikan. Apabila nilai absolute nya signifikan maka data memiliki gejala heteroskedastisitas.

4. Uji autokorelasi

Observasi yang berurutan sepanjang waktu antara satu sama lain akan memunculkan gejala autokorelasi. Masalah autokorelasi timbul karena adanya residual tidak bebas dari suatu observasi ke observasi lainnya (Mardiyati et al,2012). Uji 
D-W dapat digunakan untuk melihat adanya penyakit autokorelasi. Batas nilai dari metode Durbin-Watson adalah: (1) nilai D-W yang besar atau diatas 2 berarti tidak ada autokorelasi negatif. (2) nilai D-W antara negatif 2 sampai 2 berarti tidak ada autokorelasi atau bebas autokorelasi. (3) nilai D-W yang kecil atau dibawah negatif 2 berarti ada autokorelasi.

\section{Analisis Regresi data panel}

Data yang digunakan dalam penelitian ini adalah data sekunder yang didapatkan dari Bursa Efek Indonesia yang telah dipublikasikan. Data yang digunakan merupakan data benar-benar tanpa ada manipulasi. yang secara tidak langsung didapatkan dari situs resmi keuangan perbankan.berikut uji kecocokan model yang didapatkan dalam analisis regresi data panel. Analisis ini merupakan kombinasi antara data runtun waktu dan data cross section.

Saat dilakukan pengujia uji chow untuk memilih antara penggunaan Effect Common dengan Efect Fixed dan uji Hausman untuk memilih antara Uji fixed dengan Uji Random.

\section{Common effect model (CEM)}

Model common effect model merupakan model sederhana yaitu dengan menggabungkan seluruh data time series dengan cross section, selanjutnya digunakan estimasi model dengan menggunakan OLS(Ordinary Least Square). Metode analisis ini berlaku untuk semua objek yang akan diteliti. Namun kelemahan model ini adalah ketidaksesuaian model dengan keadaan yang sebenarnya.

2. Fixed effect model (FEM)

Model data panel dengan fixed effect model mengasumsikan bahwa perbedaan mendasar antara individu dapat di akomodasikan melalui perbedaan intersepnya antar waktu sama.intersep individu merupakan intersep yang tidak dapat diketahui dan akan di estimasi. Pada umumnya memasukkan variabel Dummy variable.

3. Random Effect Model (REM)

Random Effect Model digunakan untuk mengatasi kelemahan model efeect tetap yang menggunakan Dummy Variabel. Sehingga model mengalami ketidakpastian. Penggunaan dummy variabel akan mengurangkan derajat bebas yang pada akhirnya akan mengurangi efisiensi dari parameter yang diestimasi. REM menggunakan residual yang diduga memiliki hubungan antarwaktu dan antar individu.sehingga REM mengasumsikan bahwa setiap individu memiliki perbedaan intersep yang merupakan variabel random.

\section{Uji Hipotesis}

\section{Uji F ( Uji Simultan)}

Uji Hipotesis ini berguna untuk menguji atau memeriksa apakah koefisien regresi yang terdapat perbedaan nyata yang signifikan. Pada penelitian ini nilai F-hitung akan dibandingkan dengan F-tabel 1 pada tingkat signifikan $(\alpha)=5 \%($ Erari 2014) 


\section{Uji t (Uji Parsial)}

Pengujian ini menggunakan tingkat $0,05(\alpha=5 \%)$ atau nilai signifikan. Hipotesis dapat di terima atau ditolak: (1) jika nilai signifikansi $t>0,05$ maka hipotesis ditolak (koefisien regresi tidak signifikan). (2) jika nilai signifikansi $t \leq, 5$ hipotesis diterima (Koefisien regresi signifikan)

\section{HASIL DAN PEMBAHASAN \\ Analisis Regresi Data Panel}

Analisis ini merupakan kombinasi antara data runtun waktu dan data cross section. Saat dilakukan pengujian uji chow untuk memilih antara penggunaan Effect Random dengan Efect Fixed terdapat nilai:

Tabel 1

Hasil Uji Chow dengan Likelihood Ratio

\begin{tabular}{lrrr}
\hline \hline \multicolumn{1}{c}{ Effects Test } & Statistic & \multicolumn{1}{c}{ d.f. } & \multicolumn{2}{c}{ Prob. } \\
\hline \hline Cross-section F & 6.707333 & $(7,29)$ & 0.0001 \\
Cross-section Chi-square & 38.511877 & 7 & 0.0000 \\
\hline \hline
\end{tabular}

Sumber: output eviews 8

Dalam melakukan pengujian diatas terdapat nilai probability 0,0001 yaitu menunjukkan nilai yang signifikan. Saat dilakukan uji asumsi klasik keempat uji lolos dari gejala-gejala yang memungkinkan dapat mempengaruhi data sehingga effect ini baik digunakan dibandingkan dengan Common Effect dan Random Effect.

Selain itu dilakukan uji hausman test yang mana memilih antara Random Effect dengan Common Effect terlihat hasil seperti berikut:

Dari tabel terdapat hasil probability 0.9528 besar dari 0.05.maka effect Random baik digunakan. Namun saat dilakukan pengujian uji asumsi klasik terdapat gejala pada salah satu alat uji sehingga tidak mengahasilkan hasil yang mampu menjelaskan variabel dan uji di berhentikan hanya sampai disitu.

Uji Spesifikasi Fixed Effect

Tabel 2

Uji Spesifikasi Fixed Effect

\begin{tabular}{lrrr}
\hline \hline Effects Test & \multicolumn{1}{c}{ Statistic } & d.f. & Prob. \\
\hline \hline Cross-section F & 6.707333 & $(7,29)$ & 0.0001 \\
Cross-section Chi-square & 38.511877 & 7 & 0.0000 \\
\hline
\end{tabular}

Sumber: output eviews 8

Pada tabel 2 terlihat nilai probability untuk cross section adalah 0,0001 yang mana < dari 0,05 artinya Fixed effect model merupakan model yang sesuai digunakan. 
Tabel 3

Hasil Uji Regresi Data Panel

\begin{tabular}{crrrr}
\hline \hline Variable & Coefficient & Std. Error & t-Statistic & Prob. \\
\hline \hline C & -0.674839 & 0.758455 & -0.889755 & 0.3809 \\
X1 & 2.210155 & 1.295681 & 1.705787 & 0.0987 \\
X2 & 0.178342 & 0.081782 & 2.180683 & 0.0375 \\
X3 & 0.063349 & 0.070168 & 0.902817 & 0.3741 \\
\hline \hline
\end{tabular}

Sumber: output eviews 8

Dari tabel diatas, dapat dituliskan persamaan sebagai berikut: $\mathrm{Y}=(-$ $0.674839)+2.210155 \mathrm{X} 1+0.178342 \mathrm{X} 2+0.063349 \mathrm{X} 3+\mathrm{e}$

Dimana nilai konstanta sebesar -0.674839 memiliki arti bahwa bilaKepemilikan Manajerial, Dewan Direksi, dan Leverage diasumsikan nol, maka nilai ROA akan menurun sebesar -0.674839.

\section{Hasil Uji Deskripsi Statistik}

Berdasarkan hasil analisis deskriptif statistic, maka data karekteristik sampel yang digunakan didalam penelitian ini meliputi : jumlah sampel $(\mathrm{N})$, ratarata sampel (mean), nilai maksimum, nilai minimum serta standar deviasi $(\sigma)$ untuk masing-masing variabel.

Tabel 4

Hasil Uji Deskripsi Statistik

\begin{tabular}{llllll}
\hline Variabel & $\mathrm{N}$ & Minimum & Maksimum & Mean & Standar deviasi \\
\hline (Kepemilikan Manajerial) & 40 & 0.00 & 0.85 & 0.18 & 0.25 \\
(Dewan Direksi) & 40 & 5 & 12 & 8 & 2 \\
(leverage) & 40 & 3.79 & 9.86 & 6.01 & 1.21 \\
Y(ROA) & 40 & 0.18 & 3.35 & 1.72 & 0.83 \\
\hline
\end{tabular}

Sumber: output eviews 8

Tabel 4 menggambarkan deskripsi statistik untuk masing-masing variabel yang digunakan jumlah data yang digunakan dalam penelitian ini adalah sebesar 40 data. Rata-rata persentase Kepemilikan Manajerial perusahaan sector keuangan adalah 0.18, Rata-rata Dewan Direksi 8, Rata-rata Leverage yaitu 6.01. dan ratarata $\mathrm{ROA}$ adalah 1,72 .

Tabel 5

Uji Normalitas

\begin{tabular}{cc}
\hline Jarque-bera & $\mathbf{3 . 4 9 6 8 0 5}$ \\
\hline Probability & $\mathbf{0 . 1 7 4 0 5 2}$
\end{tabular}

\section{Sumber: output eviews 8}

Dilihat dari tabel diatas pada probability variabel independen bernilai 0.174052 yang menujukkan bahwa probabilitas $>0.05$ berarti data berdistribusi normal. 
Tabel 6

Uji Multikolinearitas

\begin{tabular}{cccc}
\hline & X1 & X2 & X3 \\
\hline (Kepemilikan Manajerial & 1.000000 & 0.145919 & -0.313713 \\
(Dewan Direksi) & 0.145919 & 1.000000 & 0.033099 \\
(Leverage) & -0.313713 & 0.033099 & 1.000000 \\
\hline
\end{tabular}

Sumber: output eviews 8

Berdasarkan hasil olahan data pada tabel terlihat nilai korelasi antara sesama variabel independen $<0,8$ sehingga dapat dikatakan bahwa sesama variabel independen tidak memiliki hubungan multikolinearitas.

Tabel 7

Uji Autokolerasi

\begin{tabular}{cc}
\hline Model & Durbin Watson \\
\hline 1 & 1.191913 \\
\hline
\end{tabular}

Sumber: output eviews 8

Dari Uji Durbin-Watson pada tabel terlihat bahwa tidak terjadi autokolrasi karena nilai DW antara $-2<1,191913<2$.

\section{Tabel 8}

Uji Heteroskedastisitas

\begin{tabular}{crrrr}
\hline \hline Variable & Coefficient & Std. Error & t-Statistic & Prob. \\
\hline \hline X1 & 0.361788 & 0.631107 & 0.573260 & 0.5709 \\
X2 & 0.065725 & 0.039835 & 1.649936 & 0.1097 \\
X3 & 0.031441 & 0.034178 & 0.919919 & 0.3652 \\
C & -0.603461 & 0.369432 & -1.633484 & 0.1132 \\
\hline \hline
\end{tabular}

Sumber: output eviews 8

Pada tabel memiliki nilai probabiliti > dari 0.05 sehingga residual suatu observasi tidak saling berhubungan dan tidak adanya

Uji Hipotesis hubungan heteroskedastisitas.

1. Uji koefisien Regresi secara Simultan (Uji f)

Dari tabel 4.6 dihasilkan nilai $F$-statistic sebesar 13.77037 dengan nilai signifikan probability $F$-statistic adalah 0.0000 , tingkat probabilitasnya lebih kecil dari 0,05 atau $<0,05$. Hal tersebut mengidentifikasi bahwa semua variabel independen (Kepemilikan Manajerial, Dewan Direksi dan Leverage) berpengaruh signifikan tehadap variabel dependen (ROA).

\section{Uji koefisien Regresi Secara Parsial (Uji t)}

Uji parsial digunakan untuk mengetahui variabel bebas yang berpengaruh signifikan secara individu terhadap variabel terikat. Dari tabel 4.9 variabel yang signifikan ditandai oleh probabiliti f-statistik yaitu 0.000000 yang mana kecil dari 0.05 sehingga dengan tingkat keyakinan $95 \%$ variabel yang signifikan mempengaruhi variabel terikat. 


\section{PEMBAHASAN}

\section{Pengaruh Kepemilikan Manajerial terhadap Kinerja Keuangan (ROA)}

Dari tabel 6 dihasilkan nilai koefisien regresi untuk variabel Kepemilikan Manajerial yang diproxy oleh (ROA) sebesar 2.210155 bertanda positif dengan probability 0.0987> 0,05 yang berarti bahwa Kepemilikan Manajerial mempunyai pengaruh positif dan tidak signifikan terhadap probabilitas yang diproxy oleh ROA. Dengan demikian dapat disimpulkan hipotesis pertama ditolak.

Bathala et al (1994) mengatakan manajer akan bertindak sesuai keinginan pemegang saham yang didorong oleh adanya penyatuan kepentingan dari principal dan agen dengan tujuan dapat meningkatkan kinerja perusahaan. Kinerja manajemen dipengaruhi oleh kepemilikan manajerial, yang akan menimbulkan manajemen dapat memaksimalkan kinerjanya dan akan bertanggung jawab dalam memenuhi keinginan manajemen dan dirinya sendiri.

Hasil penelitian ini sama dengan penelitian yang dilakukan oleh (Prasetyo, 2013), yang berjudul Pengaruh Corporate Governance Terhadap Kinerja Keuangan Perusahaan GO Public di BEI yang hasilnya menunjukkan bahwapengaruh corporate governance dalam hal kepemilikan manajemen berpengaruh terhadap kinerjakeuangan perusahaan.

\section{Pengaruh Dewan Direksi Terhadap Kinerja Keuangan (ROA)}

Hasil penelitian koefisien regresi dari Dewan Direksi sebesar 0.178342. bertanda positif dengan. Probabilitas $0.0375<0,05 y$ yng artinya bahwa variabel Dewan Direksi berpengaruh positif dansignifikan terhadap kinerja keuangan (ROA). Dengan demikan dapat disimpulkan bahwa hipotesis kedua mengatakan Dewan Direksi pengaruh positif dan signifikan terhadap kinerja keuangan.Dengan demikian hipotesis kedua ditolak.

(Bodroastuti, 2009) Dewan Direksi dalam suatu perusahaan akan menentukan kebijakan yang akan diambil baik jangka pendek maupun jangka panjang. Jumlah dewan direksi yang lebih sedikit akan menciptakan komunikasi yang lebih baik di antara para direktur, koordinasi yang lebih efektif, dan tindakan yang lebih cepat dalam mengatasi masalah.

Hasil penelitian ini tidak mendukung dengan hasil penelitian yang dilakukan oleh (Widyati, 2013) yang berjudul Pengaruh Dewan Direksi, Komisaris Independen, Komite Audit, Kepemilikan Manajerial Dan Kepemilikan Institusional Terhadap Kinerja Keuangan yang hasilnyamengatakan bahwa dewan direksi yang di ukur dengan jumlah dewan direksi tidak berpengaruh signifikan terhadap kinerja keuangan perusahaan.

\section{Pengaruh Leverage terhadap Kinerja Keuangan (ROA)}

Dari tabel dihasilkan dari nilai koefisien regresi untuk variabel Leverage yang diproxy oleh ROA sebesar 0.063349 bertanda positif dengan nilai probability $0,3741>0,05$ yang berarti bahwa Leverage mempunyai pengaruh positif dan tidak signifikan terhadap kinerja keuangan (ROA). Dengan demikian dapat disimpulkan hipotesis ketiga ditolak

Menurut (Sartono,2008:263) Financial leverage merupakan penggunaan dari dana yang memiliki beban tetap dengan asumsi dapat memberi keuntungan tambahan yang besar dibandingkan beban tetap dengan tujuan agar pemegang saham mendapatkan keuntungan yang meningkat. 
Penelitian ini mendukung penelitian yang dilakukan oleh (Sumarjo, 2010) tentang Pengaruh Karakteristik Pemerintah terhadap Kinerja Keuangan yang menyimpulkan bahwa leverage berpengaruh positif terhadap kinerjakeuangan pemerintah daerah. Hal ini dikarenakan dengan semakin besarnya leverage pemerintah daerah maka pengawasan yang dilakukan oleh kreditor akan semakin ketat.

\section{SIMPULAN}

Berdasarkan hasil penelitian, dapat disimpulkan bahwa Kepemilikan Manajerial menghasilkan hipotesis bahwa Kepemilikan Manajerial mempunyai pengaruh positif dan signifikan terhadap kinerja keuangan yang di proxy oleh ROA. Hipotesis pertama ditolak. Dewan direksi berpengaruh positif dan signifikan terhadap kinerja keuangan (ROA). Hipotesis kedua ditolak. Leverage mempunyai pengaruh positif dan tidak signifikan terhadap kinerja keuangan (ROA). hipotesis ketiga ditolak.

\section{UCAPAN TERIMAKASIH}

Dalam penyusunan penelitian ini, penulis menyadari bahwa tanpa bimbingan dan bantuan dari berbagai pihak, penulis belum tentu dapat menyelesaikan penelitian ini. Untuk itu ucapan terimakasih yang sebesar-besarnya penulis sampaikan kepada: Bapak Febryandhie Ananda, SE, M.Si selaku ketua STIE “KBP” Padang yang telah memberikan bimbingan dan fasilitas selama penulis menjadi mahasiswi. Ibu Lidya Martha, SE, MM selaku wakil ketua dan sekaligus penasihat akademik angkatan 2013. Ibu Febsri Susanti, SEI, MM selaku ketua program studi manajemen Sekolah Tinggi Ilmu Ekonomi "Keuangan, Perbankan dan Pembangunan" Padang. Ibu Aminar Sutra Dewi, SE, M.Si selaku Dosen Pembimbing penulis, yang telah membimbing penulis dari awal skripsi sampai saat sekarang ini, membimbing penulis dengan penuh kesabaran, terimakasih atas segala kesempatan yang Ibu berikan semoga nasehat-nasehat yang Ibu berikan member manfaat bagi saya selamanya.

\section{DAFTAR PUSTAKA}

Afriyeni, A., \& Marlius, D. (2017). Analisis Pengaruh Harga Saham Perdana Terhadap Abnormal Return Yang Diterima Investor Studi Pada Bursa Efek Indonesia. https://doi.org/10.31219/osf.io/8z7hx

Afriyeni, A., \& Marlius, D. (2018). Analisis Pengaruh Informasi Prospektus Perusahaan Terhadap Initial Return Saham Pada Pasar Perdana Di Bursa Efek Indonesia. https://doi.org/10.31219/osf.io/kt6c4

Afriyeni, A., \& Marlius, D. (2019). Analisis Faktor-Faktor Yang Berpengaruh Terhadap Ketepatan Waktu Penyampaian Laporan Keuangan Pada Perusahaan Yang Listing Di Bursa Efek Indonesia. https://doi.org/10.31219/osf.io/rv4qf

Afriyeni, A., \& Marlius, D. (2019). Analisis Tingkat Pengembalian Dan Risiko Investasi (Studi Pada Industri Manufaktur Yang Terdaftar Di Bursa Efek Indonesia). https://doi.org/10.31219/osf.io/cfb92 
Agustia, D. (2013). Pengaruh Faktor Good Corporate Governance , Free Cash Flow , dan Leverage Terhadap Manajemen Laba. Jurnal Akuntansi Dan Keuangan,15(1), 27-42. https://doi.org/10.9744/jak.15.1.27-42

Bodroastuti, T. R. I. (2009). Pengaruh Struktur Corporate Governance terhadap Financial Distress The Influence of Corporate Governance Structure toFinancial Distress. Jurnal Keuangan, (2000).

Darwis, H. (2009). Corporate Governance Terhadap Kinerja Perusahaan. Jurnal Keuangan Dan Perbankan, 13(3).

Dewi AS. (2014). Pengaruh Good Corporate Governace dan Leverage Terhadap Kinerja keuangan Perbankan Yang terdaftar di BEI. Manajemen.

D., \& Dewi, A. S. (2018). Pengaruh Penerapan Good Corporate Governance Terhadap Kinerja Keuangan Perbankan Yang Terdaftar Di Bursa Efek Indonesia. https://doi.org/10.31219/osf.io/w5agv

Farida, Y. N. U. R., \& Herwiyanti, E. (2010). Pengaruh Penerapan Corporate Governance Terhadap Timbulnya Earnings Management Dalam Menilai Kinerja Keuangan Pada Perusahaan Perbankan Di Indonesia. JURNAL BISNIS DAN AKUNTANSI, 12(2), 69-80.

Prof. dr. sugiyono. (2015). Statistik Nonparametris Untuk Penelitian. In book (pp. 1-370). Bandung: alfabeta.

Puspitasari, F., \& Ernawati, E. (2010). Pengaruh mekanisme. Jurnal Manajemen Teori Dan Terapan, 1999(2), 189-215.

Putri, A. D., \& Mayliza, R. (2019). Pengaruh Good Corporate Governance Dan Leverage Terhadap Kinerja Keuangan Pada Perbankan Yang Terdaftar Di BEI. https://doi.org/10.31219/osf.io/b8he7

Sayidah, N. (2005). Pengaruh Kualitas Corporate Governance Terhadap Kinerja Perusahaan Publik ( Studi Kasus Peringkat 10 Besar CGPI. Jurnal Akuntansi Dan Keuangan,11(1), 1-19.

Sukamulja, S., Corporate, G., \& Gcg, G. (2002). Good Corporate Governance Di Sektor Keuangan : Dampak GCG Terhadap Kinerja Perusahaan ( Kasus di Bursa Efek Jakarta ). Jurnal Manajemen, (1), 1-25.

Totok Dewayanto *). (2008). Governance Terhadap Kinerja Perbankan Nasional Studi pada Perusahaan Perbankan yang Terdaftar di Bursa Efek Indonesia Periode 2006-2008. Jurnal Ilmu Manajemen, 5(2), 104-123.

Ujiyantho, M. A., \& Universitas, B. A. P. (2007). Corporate governance ,. Jurnal Keuangan, (6), 1-26. 
Wardhani, R. (2007). Mekanisme Corporate Governance Dalam Perusahaan -. Jurnal Akuntansi Dan Keuangan Indonesia, 4(1).

Wati, L. M. (2012). Jurnal Manajemen , Volume 01, Nomor 01, September 2012. Jurnal Manajemen, 1(September), 1-7.

Widyati, M. F. (2013). Maria Fransisca Widyati; Pen garuh Dewan Direksi .... Jurnal Ilmu Manajemen, 1(1). 